\title{
Promoting Citizenship Education through Collaborative Groups of School Leaders
}

\author{
Maria Karadimou (Corresponding author) \\ $\mathrm{PhD}$ Candidate, School of Philosophy and Education \\ Aristotle University of Thessaloniki
}

Greece

Kostis Tsioumis

Professor, School of Philosophy and Education

Aristotle University of Thessaloniki

Greece

Received: February 28, 2021

Accepted: April 15, $2021 \quad$ Published: April 22, 2021

doi:10.5296/ijld.v11i2.18363

URL: https://doi.org/10.5296/ijld.v11i2.18363

\begin{abstract}
The purpose of this study is to examine whether there is a correlation between the leader's collaborative networks (teachers, students, and the community) and the civic education provided to students in their school unit. The survey was conducted in July 2020 using a closed questionnaire. The research involved 122 primary school teachers (kindergarten teachers, teachers, and expertise teachers) who were asked to choose from a five-point scale, or from multiple answers. The survey based on the assumption that the existence of a collective and democratic climate of school administration helps to encourage teachers to address issues of education in the capacity of citizen. The results of the survey lead us to confirm our initial thought, which was the springboard for conducting this research, that those teachers who work in an environment characterised with respect and collectivity, it makes sense to be them who embrace the principles of citizenship education and consider it important to convey them on to their students.
\end{abstract}

Keywords: citizenship education, educational leadership, collaboration networks 


\section{Citizenship Education}

One of the main goals of the modern education system is the development of skills necessary for the future, through the transmission of evolving knowledge and the methods to acquire it, as well as values such as equality, respect for human rights and cultural diversity, democracy, and dignity (Nikolaou, 2006: 448). As a result, a particular challenge in a pluralistic society is to build citizenship education, which helps to cultivate a just and inclusive pluralistic nation-state, which will be perceived as legitimate by all students and groups (Banks, 2012: $68)$.

Boggs (1991: 5) defines citizenship education as:

The deliberate and systematic effort to develop the skills and attitudes that will make them effective citizens, both in their communities and in the wider world. Its purpose is to develop both citizens' understanding and judgment on public issues and to participate in decision-making through discussion and public debate.

Citizenship education plays an important role in the process of education, as students are called upon to understand the need to act as citizens of the global community in order to solve difficult problems (Banks, 2012: 63) but also how cultural, national, regional and global identities are interconnected, complex and evolving (Banks, 2004). It is a type of education that contributes to the development of attitudes, knowledge, and skills, necessary to function in cultural communities different from their own, as well as within a global community (Banks, 2012: 61).

Given that school is the suitable place to teach students the importance of participation and their responsibility as citizens, and to acquire skills and predispositions, it is vital for teacher educators to help teachers become socially minded citizens (Vander-Veldt Ponder, 2010: 84). After all, civic education can be achieved through many subjects (Etienne et.al., 2005: 2), since there is not a separate course, but a set of coordinated processes, policies, and activities, which include many of the elements of citizenship education (Atkinson, 2000).

The findings of the latest Eurydice Brief study (2018) suggest that knowledge, skills and attitudes related to citizenship education should be based on: (a) mutual and constructive interaction with others, (b) in critical thinking, (c) in socially responsible action, and finally (d) in democratic action.

We therefore conclude that the main concern of education should be the cultivation of active participation in educational and social events, the provision of students with the necessary cognitive tools, so that they can deal simple and universal problems through a critical-constructive and dialectical dimension. The role of the teacher should not be limited to what should be taught to the student and what should be thought, but to offer him the method, criteria, and tools to stand critically against any form of knowledge, to form an opinion that predicts, but also justifies the results of its decisions and actions (Kostoula-Makraki, 2008: 108-110, Banks, 2004,2012).

In order for schools to fulfil their duty to provide political education, they must discover and 
strengthen democratic ideals for marginalized students, preparing students to learn what it means to accept the concept of citizenship (Ladson-Billings, 2012: 221).

\section{Educational Leadership}

There has been a great deal of interest in educational leadership during the recent years because of the belief that it can make a significant contribution to school and student actions. Through the search for the most effective leadership style adopted by a principal, it has shown that it does not always favour the establishment of good relationships with teachers (Donald, 1977). Recent findings suggest that leadership is most effective when the leader teacher is interested in the quality of relationships (Donaldson, 2007).

Particular interest presents the research during the last decade, focusing on the principal's negative and authoritarian attitude towards teachers, from which resulted that the formation of a school culture that does not promote free expression, or collective decision-making and undermines teachers' interpersonal relationships with them, as well as among everyone, since often cooperation is targeted by the leader teacher (Koula, 2011).

In order for a school to be competitive, it is necessary to have specialized human resources, which consists of trained teachers who need the leadership of a capable leader and with the support of all of them (Bush, 2007: 391). The leader participates in a network of relationships with others who constitute the group; these individuals will accept the direction of their activities if the leader's behaviour seems to provide the required data to meet their needs (Knezevich, 1975). After all, as the term leadership reasonably argues, it includes the ability to influence others (Yuk1, 2013; Bass, 1990).

The principal has the role to create communities, where through communication will aim at shaping the organizational culture of the school (Saiti \& Saitis, 2012).

Initially through communication with the staff, the principal has to be informed about what is happening in their school unit, as well as to make clear reports on issues of practice, programmes, plans and problems of the organization (Saiti \& Saitis, 2012), where considered necessary by them a good knowledge of the issues that will be discussed, but also the early information of the association (Krypa, 2017). Encouraging educational leaders contribute significantly to strengthening collective support, but also to staff cohesion, as a feedback process that leads to building strong relationships of trust (Bryk et.al., 2010; Leithwood \& Jantzi, 1990).

Regarding the communication of the leader with the students, necessary elements are considered, such as sincere interest, respect for the student's personality, fair and pedagogical treatment of disciplinary offenses that will contribute to their smooth development and operation of the school unit (Saiti \& Saitis, 2012).

Finally, developing a relationship between the teacher and the parent is a vital undertaking in developing schools as learning communities (Schussler, 2003).

We therefore conclude that leaders who have the potential to create an environment of school trust for all members of the educational community - teachers, students, parents - can be 


\section{MInstitute Macrothink $_{\text {Institis }}$}

"guides to change" (Bryk et al., 2010).

\section{Methodology}

\subsection{Research Reasoning}

Many studies have been conducted during the past years regarding educational leadership, examining leadership styles, the social changes taking place (Hoy, \& Miskel 2004; Dimmock, $\&$ Walker, 2002), while others have examined in detail the concept of citizenship education (Kennedy et.al., 2010; Banks, 2008). Findings regarding the correlation of these two parameters are minimal. The empirical data so far for the relationship between these two parameters emerge from qualitative studies such as Pashiardis, Georgiou, \& Georghiou (2009), and Scheerens $(2009,2011)$, where they try to connect educational leadership with citizenship education.

According to Remy, \& Wagstaff (1982), school leaders can implement their leadership in relation to citizenship education through curriculum guidance and teaching, through the development of a school culture spirit, and finally through fostering relationships between the school, the teachers, and the community. On this occasion, an effort is made to record teachers' views on educational leadership, the existence of collaborative networks as well as citizenship education, and to be examined whether the creation of collaborative networks by the educational leader can contribute to the promotion of citizenship education. To date, research has been conducted that highlight correlations between leadership styles and how they can affect school leaders' relationships with teachers, the community, parents, and policy (Smith, \& Piele, 2006), but without providing information on citizenship education. After all, one of the main concerns of the multidimensional role of school leaders is the creation of cooperation networks as well as to lead in issues related to the training of their staff. Finally, another key task is their ability to create the necessary conditions to promote the development of active citizens, who will be ready tomorrow to face the challenges of society as its future citizens, which in order to succeed will have to create appropriate learning opportunities (Savvides, \& Pashiardis, 2016).

\subsection{Aim}

The purpose of this study is to examine if there is a correlation between the school leader's collaborative networks (with teachers, students and the community) with citizenship education provided to the students of their school unit.

\subsection{Research Questions}

- How do teachers perceive school leadership and the existence of collaboration networks in their school, and how do sociocultural factors influence this?

- How do teachers perceive citizenship education in their school, and how do sociocultural factors influence it?

- How does the existence of cooperation networks within the school unit affect the provided citizenship education to the students? 


\section{Macrothink}

\subsection{The sample}

The sample in the present study consists of 122 primary school teachers.

Table 1. The social and the demographic characteristics of the sample

\begin{tabular}{|c|c|c|c|c|c|}
\hline Gender & $\mathbf{N}$ & $\%$ & Training in intercultural education & $\mathbf{N}$ & $\%$ \\
\hline Male & 30 & 24,6 & Yes & 43 & 35,2 \\
\hline Female & 92 & 75,4 & No & 79 & 64,8 \\
\hline Age & $\mathbf{N}$ & $\%$ & Type of educational degree & $\mathbf{N}$ & $\%$ \\
\hline $22-30$ & 7 & 5,7 & School of pedagogics & 2 & 1,6 \\
\hline $31-35$ & 34 & 27,9 & University degree & 54 & 44,3 \\
\hline $36-40$ & 37 & 30,3 & In-service Training education & 4 & 3,3 \\
\hline $41-50$ & 29 & 23,8 & Postgraduate degree & 58 & 47,5 \\
\hline 51 plus & 15 & 12,3 & Ph.D. degree & 4 & 3,3 \\
\hline Professional occupation & $\mathbf{N}$ & $\%$ & Years of work experience & $\mathbf{N}$ & $\%$ \\
\hline Teacher & 44 & 36,1 & $1-5$ years & 22 & 18,0 \\
\hline Kindergarten Teacher & 41 & 33,6 & $6-15$ years & 65 & 53,3 \\
\hline Expertise & 37 & 30,3 & $16-25$ years & 31 & 25,4 \\
\hline Place of work & $\mathbf{N}$ & $\%$ & 26 years or more & 4 & 3,3 \\
\hline Urban area & 79 & 64,8 & & & \\
\hline Semi - urban area & 30 & 24,6 & & & \\
\hline Rural area & 13 & 10,7 & & & \\
\hline
\end{tabular}

\section{Data Analysis}

The teachers who participated in the research were asked to answer in a five-point Likert scale by choosing between (1: not at all, 2: a little, 3: enough, 4: a lot, 5: too much) and multiple-choice questions, in which they had the opportunity to choose two or three answers that express them the most. 
Table 2. The means of the statements

\begin{tabular}{|c|c|c|c|}
\hline Statement & $\mathbf{N}$ & Mean & $\begin{array}{l}\text { Std. } \\
\text { Dev. }\end{array}$ \\
\hline $\begin{array}{l}\text { 1. The principal / supervisor of my school exercises leadership under a specific regulatory } \\
\text { or legislative framework without deviating from it. }\end{array}$ & 122 & 2,98 & ,936 \\
\hline $\begin{array}{l}\text { 2. All current issues regarding my school unit are examined by the entire Teachers' } \\
\text { Association. }\end{array}$ & 122 & 3,13 & ,962 \\
\hline 3. The director / principal of my school keeps distance from the Teachers' Association. & 122 & 2,19 & 1,007 \\
\hline $\begin{array}{l}\text { 4. The director / principal of my school is limited only to the exercise of administrative } \\
\text { duties and not to dealing with pedagogical issues }\end{array}$ & 122 & 2,42 & 1,245 \\
\hline $\begin{array}{l}5.1 \text { In my school there are cooperation networks between the director / principal and the } \\
\text { teachers }\end{array}$ & 122 & 3,28 & 1,039 \\
\hline $\begin{array}{l}5.2 \text { In my school there are cooperation networks between the director / principal and the } \\
\text { parents }\end{array}$ & 122 & 3,05 & 1,011 \\
\hline $\begin{array}{l}5.3 \text { In my school there are collaboration networks between the director / principal and the } \\
\text { wider community }\end{array}$ & 122 & 2,67 & 1,016 \\
\hline $\begin{array}{l}\text { 6.1In my school the director / principal's working relationships with other teachers to } \\
\text { produce pedagogical results are based on respect }\end{array}$ & 122 & 3,38 & ,990 \\
\hline $\begin{array}{l}\text { 6.2In my school the director / principal's working relationships with other teachers to } \\
\text { produce pedagogical results are based on appreciation }\end{array}$ & 122 & 3,34 & ,984 \\
\hline $\begin{array}{l}6.3 \text { In my school the director / principal's working relationships with other teachers to } \\
\text { produce pedagogical results are based on collective decision making }\end{array}$ & 122 & 3,22 & 1,102 \\
\hline $\begin{array}{l}\text { 7.The director / principal of my school constructs, beyond the positive work environment, } \\
\text { and interpersonal relationships with teachers }\end{array}$ & 122 & 3,13 & 1,075 \\
\hline $\begin{array}{l}\text { 8. The director / principal of my school and the teachers hold meetings in addition to those } \\
\text { prescribed by law. }\end{array}$ & 122 & 2,52 & 1,085 \\
\hline $\begin{array}{l}\text { 9. The director / principal of my school raises issues for discussion that exclusively } \\
\text { concern the close working environment of teachers. }\end{array}$ & 122 & 2,87 & ,979 \\
\hline $\begin{array}{l}\text { 10. The director / principal of my school must be aware of any problems-difficulties that } \\
\text { arise in their school. }\end{array}$ & 122 & 4,28 & ,785 \\
\hline 11.1. Citizenship education at my school is a separate subject & 122 & 1,9 & 299 \\
\hline $\begin{array}{l}11.2 \text { Citizenship education at my school is included in courses, such as geography, history, } \\
\text { religion, political education }\end{array}$ & 122 & 1,8 & ,405 \\
\hline 11.3. Citizenship education at my school is embedded in all school subjects & 122 & 1,55 &, 500 \\
\hline 11.4 Citizenship education at my school is an activity outside the core curriculum & 122 & 1,77 & ,423 \\
\hline $\begin{array}{l}\text { 12.1 Citizenship education in my school contributes to: The development of ideas, beliefs, } \\
\text { desirable behaviours and attitudes }\end{array}$ & 122 & 1,52 &, 501 \\
\hline $\begin{array}{l}\text { 12.2 Citizenship education at my school contributes to: Promote basic skills and } \\
\text { problem-solving tools }\end{array}$ & 122 & 1,82 & ,386 \\
\hline $\begin{array}{l}\text { 12.3 Citizenship education at my school contributes to: Providing knowledge for political } \\
\text { literacy }\end{array}$ & 122 & 1,90 & 299 \\
\hline
\end{tabular}


12.4 Citizenship education at my school contributes to: Learning social roles and taking responsibility

$1221,53 \quad 501$

12.5 Citizenship education at my school contributes to: Developing skills for active participation in social and political processes

$122 \quad 1,74,442$

12.6 Citizenship education at my school contributes to: Learning to work in a spirit of mutual aid and teamwork

$122 \quad 1,58 \quad 495$

13.1 Citizenship education at school emphasizes in: Knowledge of society

$122 \quad 1,81 \quad 1,904$

13.2 Citizenship education at school emphasizes in: Developing students' critical thinking $122 \quad 1,48,502$

13.3 Citizenship education at school emphasizes in: Encouraging students to participate in social and political activities

$122 \quad 1,57 \quad 498$

13.4 Citizenship education at school emphasizes in: The development of values

$115 \quad 1,48 \quad, 502$

14.1 Citizenship education at my school teaches my students: To understand people with different views than theirs

$122 \quad 1,44 \quad 499$

14.2 Citizenship education at my school teaches my students: To collaborate and work in teams

$122 \quad 1,31 \quad, 465$

14.3 Citizenship education at my school teaches my students: To contribute in solving social problems

14.4 Citizenship education at my school teaches my students: To be faithful to the patriotic ideal

14.5 Citizenship education at my school teaches my students: To protect the environment $122 \quad 1,80,405$

14.6 Citizenship education at my school teaches my students: To be interested in what is happening in the world around them

$1221,54,500$

14.7 Citizenship education at my school teaches my students: To understand the meaning of the electoral process

$122 \quad 1,89 \quad 320$

15.1 In my opinion, what is the term "good-active citizen"? He who faithfully obeys the rules and the laws

$1221,81 \quad, 393$

15.2 In my opinion, what is the term "good-active citizen"? One who respects the symbol of his homeland

$122 \quad 1,92 \quad 275$

15.3 In my opinion, what is the term "good-active citizen"? The one who votes in the national elections

$122 \quad 1,92 \quad 275$

15.4 In my opinion, what is the term "good-active citizen"? The one who preserves his tradition and culture

$122 \quad 1,84 \quad, 364$

15.5 In my opinion, what is the term "good-active citizen"? The one who understands the political system of his country

$122 \quad 1,91 \quad 288$

15.6 In my opinion, what is the term "good-active citizen"? The one who knows the history of his country

$122 \quad 1,88 \quad, 330$

15.7 In my opinion, what is the term "good-active citizen"? The one who participates in public issues

$122 \quad 1,61 \quad 489$

15.8 In my opinion, what is the term "good-active citizen"? One who respects the culture of other peoples

$122 \quad 1,69 \quad, 465$ 
15.9 In my opinion, what is the term "good-active citizen"? The one who protects the environment

1221,89

15.10 In my opinion, what is the term "good-active citizen"? The one who knows and fights for everyone's rights and obligations

$120 \quad 1,49 \quad, 502$

15.11 In my opinion, what is the term "good-active citizen"? The one who has a critical attitude towards the media

$122 \quad 1,92 \quad 275$

15.12 In my opinion, what is the term "good-active citizen"? The one who actively participates in the decision-making

$122 \quad 1,64,482$

15.13 In my opinion, what is the term "good-active citizen"? One who shows respect for the different

\begin{tabular}{llll}
\hline 16. I consider my knowledge in issues related to citizenship education to be sufficient & 122 & 2,79 &, 826 \\
\hline $\begin{array}{l}17 \text { I try to keep my educational activity in line with the principles that education stands for } \\
\text { as a citizen }\end{array}$ & $\begin{array}{lll}122 & 3,46 & , 815\end{array}$
\end{tabular}

18.1 I find it difficult to apply citizenship education in my daily life due to difficulty in understanding the content

$122 \quad 1,93 \quad 249$

18.2 I find it difficult to apply citizenship education in my daily life due to the lack of maturity of students

$122 \quad 1,83 \quad 379$

18.3 I find it difficult to apply citizenship education in my daily life due to lack of time $\quad \begin{array}{lll}122 & 1,79\end{array}, 411$

18.4 I find it difficult to apply citizenship education in my daily life due to lack of knowledge

$122 \quad 1,86 \quad 348$

18.5 I find it difficult to apply citizenship education in my daily life due to lack of educational materials and tools

$122 \quad 1,58 \quad, 495$

From the influence of socio-cultural factors on educational leadership and citizenship education, the following emerged. For the independent variable sex, correlations were observed with the dependent variables $2(F=11,594, d f=1$, sig $=0,001), 3(F=14,590, d f$ $=1$, sig $=0.000), 4(F=21,651, d f=1, \operatorname{sig}=0.000)$. Regarding the independent variable study, correlations were observed with the dependent variables $8(F=\mathbf{2 . 6 4 6}$, $\mathbf{d f}=\mathbf{4}$, sig $=$ 0.037), $10(\mathrm{~F}=2.779$, df $=4$, sig $=0.030) 19(\mathrm{~F}=2.454$, df $=4$, sig $=0.050)$. For the independent variable training, correlations were observed with the dependent variables $\mathbf{1 4 . 1}$ $(\mathrm{F}=12.943$, df $=1$, sig $=0.000)$ and $14.5(F=7.798$, df $=1$, sig $=0.006)$. For the sociocultural factor work environment, correlations were observed with the dependent variables $2(\mathrm{~F}=3,292, \mathrm{df}=2$, sig $=0,041) 7(\mathrm{~F}=4,132, \mathrm{df}=2, \operatorname{sig}=0,018) 8(\mathrm{~F}=3,908, \mathrm{df}$ $=2$, sig $=0.023) 10(F=9.823, d f=2, \operatorname{sig}=0.000)$. Regarding the independent variable specialty, correlations were observed with the dependent variables $2(\mathbf{F}=\mathbf{4 , 2 0 3}, \mathbf{d f}=\mathbf{2}$, sig $=$ 0.017) $3(\mathrm{~F}=\mathbf{8 , 9 7 9}, \mathrm{df}=2$, sig $=0.000) 4(\mathrm{~F}=12,626, \mathrm{df}=2, \operatorname{sig}=0.000) 7(\mathrm{~F}=5.319, \mathrm{df}=$ 2 , sig $=\mathbf{0 . 0 0 6})$. Finally, for the independent variable years of service a correlation emerged with the dependent variable $2(\mathbf{F}=\mathbf{2 . 9 6 6}, \mathbf{d f}=\mathbf{3}, \mathbf{s i g}=\mathbf{0 . 0 3 5})$.

The research hypotheses examine the existence of correlation between cooperation networks and citizenship education.

First Hypothesis: In case there are more cooperation networks in a school between the 
principal and the teachers (5.1), with the parents (5.2), with the wider community (5.3), the more:

- teachers feel confident about their knowledge in citizenship education (16), where the correlation analysis showed a positive linear correlation between 5.1 and 16 with $(r=0.340$, $\mathrm{p}<0.01)$, with 5.2 with 16 with $(r=0.201, p<0.05)$ and 5.3 with 16 with $(r=0.320$, $p$ $<0.01$,

- teachers work very hard to integrate citizenship education into their daily educational reality (17), where the correlation analysis showed a positive linear correlation between 5.1 and 17 with $(r=0.180, p<0.05)$ and no correlation was observed with 5.2 and 5.3,

- It is important for teachers to apply citizenship education daily (19), where there was no correlation with $5.1,5.2,5.3$.

Second Hypothesis: While the most the school principal working relationship with teachers to produce pedagogical results is based on respect (6.1), collective decision making (6.2), appreciation (6.3), the more:

- teachers feel confident about their knowledge regarding citizenship education (16), where analysis showed a positive linear correlation between 6.1 and 16 with $(r=0.271, p<0.05)$, at 6.2 with 16 with $(r=0.292, p<0.01)$ and 6.3 with 16 with $(r=0.261, p<0.05)$,

- teachers are trying to import citizenship education into their daily educational reality (17), where analysis showed a positive linear correlation between 6.1 and 17 with $(r=0.214$, $p$ $<0.05$ ), while no correlation was observed with $6.2,6.3$,

- teachers consider it important to apply citizenship education daily (19), where analysis showed a positive linear correlation between 6.1 and 19 with $(r=0.251, p<0.01)$, at 6.2 with 19 with $(r=0.245, p<0.01)$ and 6.3 with 19 with $(r=0.225, p<0.05)$.

Third Hypothesis: The more the school principal creates beyond the positive work environment and interpersonal relationships with teachers (7), the more:

- teachers feel confident about their knowledge regarding citizenship education (16), where analysis showed a positive linear correlation between 7 and 16 with $(r=0.339, p<0.01)$,

- they are trying harder to integrate citizenship education into their daily educational reality (17), where no correlation was observed,

- teachers consider important to apply citizenship education in a daily basis (19), where analysis showed a positive linear correlation between 7 and 19 with $(r=0.301, p<0.01)$.

Fourth Hypothesis: The more meetings, than those prescribed by law, are held by the school principal and teachers $(8)$, the more:

- confident the teachers feel about their knowledge in citizenship education (16), where analysis showed a positive linear correlation between 8 and 16 with $(r=0.227, p<0.05)$,

- teachers try very hard to integrate citizenship education into their daily educational reality 
(17), where no correlation was observed,

- teachers consider it important to apply citizenship education daily (19), where analysis showed a positive linear correlation between 7 and 19 with $(r=0.193, p<0.05)$.

Fifth Hypothesis: While most of the current issues concerning the school unit are examined by teachers' as a whole (2), the more:

- teachers feel confident about their knowledge in citizenship education (16) where analysis showed a positive linear correlation between 2 and 16 with $(r=0.223, p<0.05)$,

- teachers try very hard to integrate citizenship education into their daily educational reality (17), where no correlation was observed,

- teachers consider it important to apply citizenship education daily (19), where analysis showed a positive linear correlation between 2 and 19 with $(r=0.222, p<0.05)$.

Sixth Hypothesis: The more distant the school principal is from the rest of the teachers (3), the less:

- teachers feel confident in their knowledge of citizenship education (16),

- teachers try to integrate citizenship education into their daily educational reality (17),

- consider it important to apply citizenship education daily (19), where no correlation was observed with any of the above.

\section{Conclusions}

The analysis regarding gender showed that women consider more than men that their school principal works in a spirit of collectivity, does not keep distance from the school teachers, is not satisfied with simple application of administrative issues, and deals with pedagogical issues. In addition, they claim that the school principal holds more meetings than those prescribed by law, without being limited to issues of the close work environment and they state the existence of networks between the manager and the parents. We assume that the positive attitude of women regarding the managers and their school principals is reflected by a projection of leadership that women themselves would apply if they were in their position, as evidenced by the findings of Collard's research (2001), in a survey at Australian schools which showed that women were more willing to set up a counselling and co-operational school where staff would take decisions. Moreover, as Bjork (2000: 11) points out, "women tend to use communicative forms of administration, as opposed to men who use the power of control and rules, which they often impose in silence." No significant correlation observed with the sociocultural factor age.

Regarding the variable studies, statistical significance emerged as to whether the Principal should be aware of all the current issues of their school as well as how important they consider the application of citizenship education in their daily educational reality, where in both cases, people who have acquired education beyond the basic (In-service Training education, postgraduate, doctoral) are more positive. This could be explained by the fact that 
the latter have richer experience, which plays a role in their spiritual openness and flexibility, but also in the further development of their critical ability (Kohn, \& Schooler, 1983), while simultaneously contributes to be open to non-stereotypical ideas (Schwartz, 2003: 10).

It is worth mentioning that teachers who have received training in intercultural education tend to believe that through education that they provide to their students for citizenship they learn to understand people with different views than theirs, in contrast to those who do not, as well as they claim to teach them how to protect the environment. It makes sense for those people to consider important to promote understanding of different points of view, since intercultural education itself strongly promotes independent thinking, receptivity to change and respect for individual freedom (Huber, \& Mompoint-Gaillard, 2011).

Regarding the variable work environment, people who work mainly in urban areas argue that current issues are addressed from the teachers as a whole, in addition to the positive atmosphere in their school, there are also interpersonal relationships, that more meetings are held than those prescribed by law, and finally they consider it necessary for the principal to be informed about all current issues in his school. The more the work environment tends towards the rural, the more slackness is noted in the above. This is probably related, according to the theory of Fiedler (1976), with the fact that leadership is determined by a group of variables related to the work environment, and the effectiveness of leadership is related to the circumstances in which the leader acts. Thus, we assume that urban school units, which are usually crowded, are considered more necessary for their effectiveness to create collaborative climate, which will help solving the issues that arise at regular intervals.

Particularly, the findings regarding specialism teachers are interesting, where kindergarten teachers show a spirit of collectivity and cooperation, existence of interpersonal relationships with the absence of distances from the Head of the Teachers' Association, while arguing that they are not limited to administrative duties, in contrast to teachers and specialism teachers, who tend to wary more for the above. This is logical to happen in a kindergarten, since according to the Legislation, the Kindergarten principal has a full teaching schedule fully supporting the needs of a class. In addition, the small capacity of kindergartens, in most of them single-seater to three-seater, results to develop interpersonal relationships between the staff and to decide together on current issues. Finally, the greater flexibility regarding the curriculum and the activities of kindergartens encourages and favours the cooperation between the kindergarten teachers.

Finally, the years of service factor showed that the less work experience a teacher has, the less he believes that current issues are addressed by the entire Teachers' Association, while the more experience there is, the greater is the belief that there is a collective approach to school issues and has a clearer picture of the school function and the educational community as a whole. We assume that this relies on low self-confidence of teachers with lesser work experience, while more experienced teachers appear more confident for their views and substantiate their point of view based on their professional experience (Huberman, 1988).

The results obtained from the correlation process between our variables showed that there are positive linear correlations between the cooperation networks in a school unit and citizenship 
education. More specifically, according to the profile of teachers who consider their knowledge in citizenship education to be sufficient, who strive to have their educational activity aligned with the principles of citizenship education, and those who consider it important to teach it to their students, are those people who point out that in their school unit the current issues are examined by the whole Teachers' Association. These teachers feel the Principal close to them and not distanced, since he tries to maintain interpersonal relationships with them. In addition, they note the existence of networks in their school unit between the Principal and themselves, the Principal with the parents and with the wider community, while emphasizing that their working relationships for the production of pedagogical results are based on respect, collective decision making and appreciation. Finally, they point out that the Principal of their school unit organizes meetings beyond those prescribed by law, contributing to better working relationships. Consequently, the cooperative, collective, democratic, and positive climate of school administration plays an important role in the development of a more substantial relationship between teachers as a methodology for managing school reality.

Of the above, it becomes clear that the teachers who perceive citizenship education and consider it important for students and try to manage their daily educational reality based on it, are those people who enjoy a climate of cooperation and collectivity in their school, and they feel equal members of a team where everyone's views are valued. It is about teachers who understand the value of being a teacher and try through mutual respect and appreciation and beyond the number of formal meetings, to achieve the best pedagogical results for their students. The principal is not a distant figure for them, but a member of a team of which he leads, but without abridging other members.

The above conclusions are further supported by additional research data. In particular, Oguz's (2010) research shows a positive correlation between teachers' organizational citizenship behaviors and transformational forms of leadership, where the leader teacher views the teacher as part of the organization. The research of Abdullahi, Anarfo, \& Anyigba, (2020), argues that the implementation of a democratic transformative leadership has a positive effect on the organizational behavior of teachers' citizenship, as opposed to the results of the implementation of an authoritarian leadership model. Lian, \& Tui's (2012) research argues that the implementation of transformational leadership can be positively related to state organizational citizenship behavior, while on the contrary results have resulted in the implementation of transactional leadership. In Roncesvalles, \& Gaerlan, (2020) research it is observed that the implementation of authentic leadership positively promotes the organizational citizenship behavior by teachers in higher education. Finally, the same influence results arise from the research of Hunsaker (2016) where there is a positive influence of intellectual leadership on the organizational behavior of teachers' citizenship. On the contrary, a survey by Savvides, \& Pashiardis (2016) argues that there has been no direct or indirect effect of educational citizenship leadership school derivatives, which may be due to several factors, the most important of which is the low impact of citizenship education on the Cypriot school.

Despite all these, teacher involvement in decision-making is considered as creating bonds 
between principals and teachers (Sergiovanni, 1992) and at the same time being a "change initiative" focusing on an alternative strategy for school management (Conley, \& Bacharach, 1990; Goldman, 1992). This leads us to confirm our initial thought, which was the springboard for conducting this research, that teachers working in an environment characterised with respect and collectivity, it makes sense to be those teachers who embrace the principles of citizenship education and consider it important to convey them on to their students.

\section{Recommendations}

This research sought to investigate the existence of a correlation between the collaborative networks developed by the leader teacher in the modern Greek school with the citizenship education provided by teachers to their students. This is a small survey of Primary Education teachers who were asked to answer self-reporting questions. This leads us to the conclusion that there is a chance that the above study does not adequately or satisfactorily reflect the role of the educational leadership, in particular the cooperation networks and their impact on the citizenship education provided. These specific restrictions lead to difficulty in generalization for the Greek school. However, it is a research approach that seeks to contribute to the dialogue about how the style of educational leadership is directly related to the provided citizenship education to students and how teachers who feel part of a whole and that their word has power, also want to educate their students on issues of citizenship. In future research it would be interesting to explore through a more extensive quantitative sample, but also through interviews, the attitude of teacher leaders regarding citizenship education, in order to further enrich the reflection on this topic. Moreover, it would be interesting to explore the above in secondary school teachers, in order to compare the results, since each level of education serves different purposes.

\section{References}

Abdullahi, A. Z., Anarfo, E. B., \& Anyigba, H. (2020). The impact of leadership style on organizational citizenship behavior: does leaders' emotional intelligence play a moderating role?. Journal of Management Development. https://doi.org/10.1108/JMD-01-2020-0012

Atkinson, W. (2000). Are schools ready for citizenship education. In N. Pearce, \& J. Hallgarten (Eds.), Tomorrow's citizens - critical debates in citizenship and education. London: Institute for Public Policy Research.

Banks, J. A. (2004). Introduction: Democratic citizenship education in multicultural societies. In J. A. Banks (Ed.), Diversity and citizenship education: Global perspectives (pp. 3-15). San Francisco: Jossey-B.

Banks, J. A. (2008). Diversity, group identity, and citizenship education in a global age. Educational Researcher, 37(3), 129-139. https://doi.org/10.1177\%2F002205741419400302

Banks, J. (2012). Democratic Citizenship Education in Multicultural Societies in Diversity and Citizenship Education - A Global Perspective. Athens: Pedio.Bass, B.M. (1990). Bass and Stodgill's handbook of leadership. New York: Free Press. 


\section{Macrothink}

International Journal of Learning and Development

ISSN 2164-4063 2021, Vol. 11, No. 2

Boggs, D. L. (1991). Adult Civic Education. Springfield: Charles Thomas.

Bryk, A. S., Sebring, P. B., Allensworth, E., Luppescu, S., \& Easton, J. Q. (2010). Organizing schools for improvement: Lessons from Chicago. Chicago, IL: University of Chicago Press.

Bush, T. (2007). Educational leadership and management: Theory, policy and practice. South African journal of education, 27(3), 391-406.

Collard, J. L. (2001). Leadership and gender: An Australian perspective. Educational Management \& Administration, 29(3), 343-355. https://doi.org/10.1177/0263211X010293008

Dimmock, C., \& Walker, A. (2002). School leadership in context-societal and organizational cultures. In T. Bush \& L. Bell (Eds.), The principles and practice of educational management (pp. 70-85). London:Paul Chapman.

Donald, Th. M. (1977). The effect of principal leadership style on social grouping among teachers. (Phd Thesis). Teachers College, Columbia University.

Donaldson, G. (2007). What Do Teachers Bring to Leadership? Educational Leadership, 65(1), 26-29.

European Commission/EACEA/Eurydice. (2017). Citizenship education at school in Europe2017: Eurydice report.

Fiedler, F. E. (1976). A theory of leadership effectiveness. New York: McGrawHill

Goldman, J. P. (1992). When Participatory Management Attracts No Buyers. School administrator, $49(1), 15$.

Hoy, W. K., \& Miskel, C. G. (2004). Educational administration, policy, and reform: Research and measurement. Greenwich: Information Age.

Huber, J., \& Mompoint-Gaillard, P. (2011). Teacher education for change: the theory behind the Council of Europe Pestalozzi Programme (Vol. 1). Council of Europe.

Huberman, M. (1988). Teacher careers and school improvement. Journal of curriculum studies, 20(2), 119-132. https://doi.org/10.1080/00220272.1988.11070783

Hunsaker, W. D. (2016). Spiritual leadership and organizational citizenship behavior: relationship with Confucian values. Journal of Management, Spirituality \& Religion, 13(3), 206-225. https://doi.org/10.1080/14766086.2016.1159974

International Association for the Evaluation of Educational Achievement (n.d.). International Study of Civic Education. Teacher Questionnaire. Retrieved June 22, 2020, from https://www.terpconnect.umd.edu/ jtpurta/Original\%20Documents/CivTQ.PDF 


\section{Macrothink}

Kennedy, K. J., Lee,W. O., \& Grossman, D. L. (Eds.). (2010). Citizenship pedagogies in Asia and the Pacific. Hong Kong: Comparative Education Research Centre.

Knezevich, S. (1975). Administration of public education. New York: Harper \& Row.

Krypa, M. (2017). The Importance of Communication, Cooperation of the Leader in the Process of Leadership in Education. European Journal of Multidisciplinary Studies, 2(1), 7-14. https://dx.doi.org/10.26417/ejms.v4i1.p7-14

Koula, B. (2011). The interpersonal relationships of school principals and teachers. contribution to the effective operation of the school unit (Doctoral dissertation). Retrieved from https://www.didaktorika.gr/eadd/bitstream/10442/25165/1/25165.pdf

Ladson-Billings, G. (x. H.). Citizenship Culture - The Challenge of Racialized Citizenship in the United States, in Banks, J. (2012) Diversity and Citizenship Education - A Global Perspective. Athens: Pedio.

Leithwood, K., \& Jantzi, D. (1990). Transformational leadership: How principals can help reform school cultures. School effectiveness and school improvement, 1(4), 249-280. https://doi.org/10.1080/0924345900010402

Lian, L. K., \& Tui, L. G. (2012). Leadership styles and organizational citizenship behavior: The mediating effect of subordinates' competence and downward influence tactics. Journal of Applied Business and Economics, 13(2), 59-96.

Makraki, N. K. (2008). The importance and role of the active citizen in the context of education for sustainable development in active citizenship and education. Balias, S. (ed.). Thessaloniki: Papazisi.

Nikolaou, S. M. (2006). From Citizenship to European Citizenship in a Democratic State The Role of Education, 3rd Panhellenic Conference on "Critical, Creative, Dialectical Thinking in Education: Theory and Practice".

Oğuz, E. (2010). The relationship between the leadership styles of the school administrators and the organizational citizenship behaviours of teachers. Procedia-Social and Behavioral Sciences, 9, 1188-1193. https://doi.org/10.1016/j.sbspro.2010.12.305

Pashiardis, P., Georgiou, M., \& Georghiou, M. (2009). In Scheerens, J. (Ed.), Informal learning of active citizenship at school: An international comparative study in seven European countries (pp. 51-74). Amsterdam, Netherlands: Springer

Remy, R. C., \&Wagstaff, L. H. (1982). Principals can exert a leadership role in citizenship education. NASSP Bulletin, 66(454), 55-62. https://doi.org/10.1177\%2F019263658206645410 


\section{Macrothink}

International Journal of Learning and Development

ISSN 2164-4063

2021, Vol. 11, No. 2

Roncesvalles, M. C. T., \& Gaerlan, A. A. (2020). Authentic Leadership and Teacher Morale: Impact on Organizational Citizenship Behavior in Higher Education. International Journal of Advanced Research and Publications, 4(3), 85-94. http://dx.doi.org/10.21474/IJAR01/10296

Savvides, V., \& Pashiardis, P. (2016). An exploration of relationships between leadership and student citizenship outcomes in Cyprus middle schools. Educational Administration Quarterly, 52(3), 497-526. https://doi.org/10.1177/0013161X16638415

Saiti, A., \& Saitis, Ch. (2012). The principal in the modern school. Athens: Self-published

Schwartz, S. H. (2003). A proposal for measuring value orientations across nations. Questionnaire package of the european social survey, 259(290), 261.

Scheerens, J. (2009). Aims and scope of the study. In J. Scheerens (Ed.), Informal learning of active citizenship at school: An international comparative study in seven European countries (pp. 1-10). Dordrecht, Netherlands: Springer.

Scheerens, J. (2011). Indicators on informal learning of active citizenship at school. Educational Assessment, Evaluation and Accountability, 23, 201-222. https://doi.org/10.1007/s11092-011-9120-8

Schussler, D. L. (2003). Schools as learning communities: Unpacking the concept. Journal of school leadership, 13(5), 498-528. https://doi.org/10.1177\%2F105268460301300501

Sergiovanni, T. J. (1992). Moral leadership: Getting to the heart of school improvement. New York: Jossey-Bass.

Smith, S. C., \& Piele, P. K. (2006). School leadership: Handbook for excellence in student learning (4th ed.). Thousand Oaks, CA: Corwin Press.

Yukl, G. A. (2013). Leadership in organizations (8th ed.). India: Pearson Education. Retrieved from https://www.academia.edu/35120132/Yukl_Gary._Leadership_in_Organizations?auto=downl oad

\section{Copyright Disclaimer}

Copyright for this article is retained by the author(s), with first publication rights granted to the journal.

This is an open-access article distributed under the terms and conditions of the Creative Commons Attribution license (http://creativecommons.org/licenses/by/4.0/). 